\title{
Pelatihan Manajemen Rekam Medis dan Informasi Kesehatan di Puskesmas Weru Kabupaten Sukoharjo
}

\author{
Fahmi Hakam* \\ Prodi. Rekam Medis dan Informasi Kesehatan, FKM, Universitas Veteran Bangun Nusantara \\ fahmihakam01@gmail.com
}

\begin{abstract}
ABSTRAK
Dengan meningkatkan kualitas tenaga perekam medis pada sarana pelayanan kesehatan, sehingga mampu melakukan pengumpulan data secara komunikatif. Selain itu juga mampu melakukan pendataan secara benar, melakukan analisis kuantitatif-kualitatif, perbaikan tata kelola manajemen unit kerja rekam medis sesuai dengan standar yang berlaku. Sehingga dapat menghasilkan sumber informasi dalam menghasilkan informasi kesehatan yang akurat. Kegiatan pengabdian masyarakat ini, bertujuan untuk meningkatkan pengetahuan dan kompetensi tenaga perekam medis di puskesmas, serta ada perbaikan manajemen pengelolaan rekam medis di puskesmas. Dalam Pengabdian Kepada Masyarakat ini tim pelaksana menggunakan analisa studi dan pemberian intervensi (pelatihan) kepada petugas rekam medis di Puskesmas, yang dilakukan dengan dua tahap, yaitu: 1) Menggambarkan karakteristik mitra, permasalahan dan kebutuhan dari tenaga rekam medis di Puskesmas. 2) Memberikan intervensi berupa pelatihan tentang manajemen unit kerja rekam medis (UKRM). Metode pelatihan dilakukan dengan interaktif, penyampaian materi (Teori dan Praktik) dan mengukur kemampuan peserta dengan : Pre-Test dan Post-Test, serta melakukan monitoring dan evaluasi pemberian pelatihan. Hasil dari pelaksanaan pengabdian di puskesmas weru : 1) Petugas puskesmas sudah semakin memahami pengelolaan dan manajemen UKRM di puskesmas. 2) Masih banyak ditemukan permasalahan duplikasi No.RM, kurangnya monitoring kualitas dan kelengkapan. 3) Pelaksanaan kegiatan ini mendapat respon yang baik dari kepala puskesmas dan para peserta yang merupakan petugas di UKRM.
\end{abstract}

Kata kunci : Rekam Medis, Puskesmas, Pelatihan UKRM

Received: December, 26, 2019

Revised: January 19, 2020

Accepted: February 27, 2020

This is an open-acces article distributed under the terms of the Creative Commons Attribution-ShareAlike 4.0 International License.

\section{PENDAHULUAN}

Puskesmas adalah fasilitas pelayanan kesehatan yang menyelenggarakan upaya kesehatan masyarakat dan upaya kesehatan perseorangan tingkat pertama, dengan lebih mengutamakan upaya promotif dan preventif, untuk mencapai tujuan pembangunan kesehatan di wilayah kerjanya dalam rangka mendukung terwujudnya kecamatan sehat (Kemenkes,2014). Puskesmas adalah unit pelaksana teknis dinas kesehatan kabupaten atau kota yang bertanggungjawab menyelenggarakan pembangunan kesehatan di suatu wilayah kerja. Sebagai unit pelaksanateknis (UPT) dinas kesehatan kabupaten atau kota, 


\section{Journal of Community Engagement in Health}

http://jceh.org

ISSN: 2620-3758 (print); 2620-3766 (online)

https://doi.org/10.30994/jceh.v3i1.58

Vol.3 No.1. March 2020. Page.116-122

puskesmas berperan menyelenggarakan sebagian dari tugas teknis operasional dinas kesehatan kabupaten atau kota dan merupakan unit pelaksana tingkat pertama serta ujung tombak pembangunan kesehatan di Indonesia (Depkes RI, 2006).

Berdasarkan Peraturan Menteri Kesehatan No 269/ Menkes/ Per/ III/ 2008 menyatakan bahwa Rekam Medias adalah berkas yang berisikan catatan dan dokumen tentang identitas pasien, pemeriksaan, pengobatan, tindakan dan pelayanan yang telah diberikan kepada pasien (Kementrian Kesehatan RI 2008).

Rekam medis mempunyai tujuan yakni dan mempunyai banyak aspek didalamnya aspek administrasi, hukum, keuangan, Pengabdian Kepada Masyarakat, pendidikan serta dokumentasi. Dengan banyak aspek yang dimiliki maka pengelolaan manajemen rekam medis yang baik adalah hal sudah seharusnya dilakukan oleh rumah sakit (Nurcahyo 2013).

Manajemen rekam medis dan informasi kesehatan adalah upaya pemeliharaan, pengelolaan dan manajemen dokumen rekam medis/ kesehatan, baik dengan cara konvensional (paperbased), maupun dengan berbasis elektronik di setiap fasilitas pelayanan kesehatan (Puskesmas). Pada implementasinya bidang ini memberikan kontribusi yang besar terhadap sistem pelayanan kesehatan dan peningkatan mutu dalam pelayanan kesehatan (Hakam 2016).

Persyararatan Akreditasi mempunyai fungsi dan tujuan sarana Pelayanan Kesehatan yang menyelenggarakan pelayanan berupa pelayanan rawat jalan, pelayanan rawat inap, Unit Gawat Darurat, pelayanan rujukan yang mencakupi pelayanan Rekam Medis dan penunjang medis serta dimanfaatkan untuk pendidikan, pelatihan, dan penelitian bagi para tenaga kesehatan di Puskesmas (Susanto \& Sukadi 2011).

Puskesmas Kecamatan Weru merupakan unit pelaksana teknis kesehatan di bawah supervisi Dinas Kesehatan Kabupaten Sukoharjo. Secara umum, mereka harus memberikan pelayanan preventif, promotif, kuratif sampai dengan rehabilitatif baik melalui upaya kesehatan perorangan (UKP) atau upaya kesehatan masyarakat (UKM).

Berdasarkan analisis masalah yang didapatkan, bahwa hampir $80 \%$ petugas Rekam Medis di Puskesmas Kab. Sukoharjo bukan berlatar belakang dari pendidikan Rekam Medis. Kebanyakan dari mereka, adalah lulusan SMP, SMA dan lulusan dari D3/S1 Non-Rekam Medis. Sedangkan hanya 20\% saja, petugas di Unit Rekam Medis yang berlatar belakang pendidikan D3 Rekam Medis. Pengelolaan dan manajemen rekam medis yang kurang optimal, menyebabkan pencatatan dan pelaporan menjadi terhambat, sehingga berpengaruh juga terhadap pelayanan yang diberikan.

Kemampuan pengelolaan dengan manajemen yang rapi, pengkodean yang sistematis dan benar, serta update tentang manajemen informasi kesehatan menjadi salah satu syarat utama bagi petugas rekam medis yang handal dan professional. Maka dari itu, kami bertujuan untuk memeberikan pelatihan kepada petugas rekam medis di puskesmas.

\section{METODE}

Kegiatan Sosialisasi dan Pelatihan Manajemen Rekam Medis dan Informasi Kesehatan kepada Petugas Unit Kerja Rekam Medis (UKRM) di Puskesmas, dengan menggunakan metode diskusi interaktif antara fasilitator dan peserta kegiatan.

Sasaran Pengabdian Kepada Masyarakat adalah Petugas Unit Rekam Medis di Puskesmas Weru. Karena berdasarkan analisis masalah yang didapatkan, bahwa hampir 80\% petugas Rekam Medis di Puskesmas Kab. Sukoharjo bukan berlatar belakang dari pendidikan Rekam Medis. Kebanyakan dari mereka, adalah lulusan SMP, SMA dan 


\section{Journal of Community Engagement in Health}

http://jceh.org

ISSN: 2620-3758 (print); 2620-3766 (online)

https://doi.org/10.30994/jceh.v3i1.58

Vol.3 No.1. March 2020. Page.116-122

lulusan dari D3/S1 Non-Rekam Medis. Sedangkan hanya 20\% saja, petugas di Unit Rekam Medis yang berlatar belakang pendidikan D3 Rekam Medis.

Karena tingkat pendidikan yang rendah, ketidak sesuaian kompetensi, kurangnya upgrade pengetahuan tentang keilmuan rekam medis, sehingga menyebabkan manajemen dan tata kelola, serta pelayanan di unit rekam medis menjadi kurang optimal.

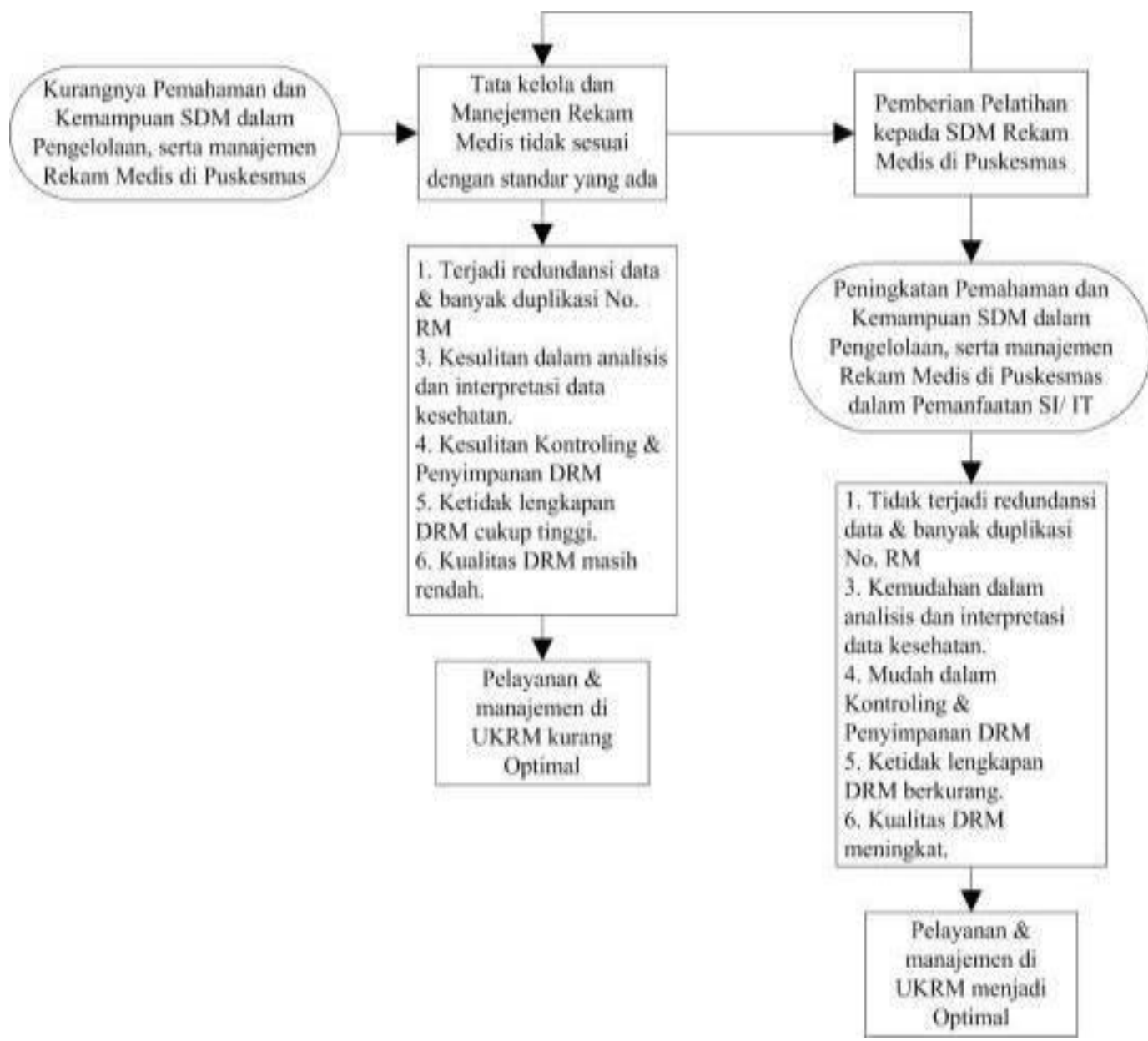

Gambar 1. Alur Kegiatan dan Kerangka Pemecahan Masalah

\section{HASIL}

1. Analisis Kondisi dan Situasi di UKRM

Tabel 2. SDM UKRM Puskesmas Weru

\begin{tabular}{|l|l|l|}
\hline No & Tingkat Pendidikan & Jumlah \\
\hline 1 & SMA & 4 \\
\hline 2 & D3 (Rekam Medis) & 1 \\
\hline 3 & S1 (Kesehatan Masyarakat) & 1 \\
\hline 4 & S1 Profesi (Keperawatan) & 2 \\
\hline
\end{tabular}

Dari hasil diskusi saat pelatihan dan pendampingan, diperoleh beberapa poin yang menjadi masalah utama di unit kerja rekam medis, diantaranya :

a. Kurangnya pengetahuan petugas UKRM di puskesmas tentang manajemen pengelolaan rekam medis yang benar. 
b. Banyaknya duplikasi No.RM, Kurangnya monitoring kualitas dan kelengkapan.

c. Ketidaksesuaian kompetensi para petugas UKRM di puskesmas, disebabkan karena kurangnya jumlah lulusan dari tenaga perekam medis. Sehingga mengakibatkan manajemen rekam medis menjadi kurang optimal.

\section{Jumlah kunjungan di UPTD Puskesmas Weru}

Berdasarkan data yang didapat, jumlah pasien di UPTD Puskesmas Weru periode tahun 2017-2019 adalah sebagai berikut :

Tabel 1. Jumlah Kunjungan Pasien Tahun 2017 sampai 2019

\begin{tabular}{|l|l|l|}
\hline \multirow{2}{*}{ Tahun } & \multicolumn{2}{c|}{ Jumlah Pasien } \\
\cline { 2 - 3 } & \multicolumn{1}{|c|}{ Rawat Jalan } & \multicolumn{1}{c|}{ Rawat Inap } \\
\hline 2017 & 79.485 & 2.112 \\
\hline 2018 & 65.595 & 1.920 \\
\hline 2019 & 55.569 & 1.828 \\
\hline
\end{tabular}

\section{Prosedur tetap bagian unit rekam medis di UPTD Puskesmas Weru}

a. Prosedur tetap bagian pendaftaran rawat jalan

UPTD Puskesmas Weru telah memiliki prosedur tetap pelayanan pasien bagian pendaftaran rawat jalan yang telah ditetapkan oleh Kepala UPTD Puskesmas Weru dengan nomor dokumen SOP/UKP/PDFT/001/2018 pada tanggal 05/01/2018 dengan nomor revisi 01.

b. Prosedur tetap bagian filing

UPTD Puskesmas Weru memiliki prosedur tetap pelayanan pasien bagian filing yang telah ditetapkan oleh Kepala UPTD Puskesmas Weru dengan nomor dokumen SOP/UKP/RM/007/2018 pada tanggal 05/01/2018 dengan nomor revisi 00 .

\section{Kegiatan}

a. Teknis Acara dan Kegiatan

Program pengabdian masyarakat yang dilakukan menekankan pada peningkatan pengetahuan kepada petugas rekam medis di puskesmas, terkait manajemen dan pengelolaan rekam medis yang baik dan benar. Maka dari itu, kegiatan pelatihan dilakukan dengan menggunakan pendekatan masalah yang ada di puskesmas dan kebutuhan SDM.

Adapun kegiatan pengabdian masyarakat yang dilakukan meliputi tahap persiapan dan pelaksanaan. Tahap persiapan SDM. Penyusunan Materi dan persiapan tekknis. Tahap pelaksanaan terdiri dari pengkajian, perencanaan, implementasi, evaluasi dan rencana tindak lanjut 


\section{Journal of Community Engagement in Health}

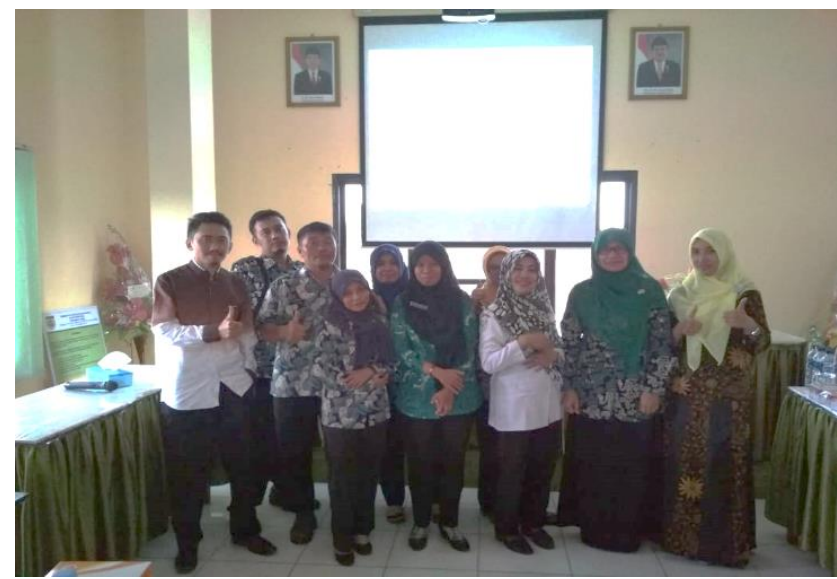

Gambar 2. Kegiatan Pendampingan Manajemen dan Tata Kelola UKRM

b. Materi Pelatihan

Berikut merupakan lingkup materi pelatihan manajemen rekam medis di Puskesmas :

1) Pengantar dan Implementasi Manajemen Rekam Medis

2) Pengelolaan Unit Rekam Medis (Akreditasi Puskesmas)

3) Isi, Struktur, Tipe dan Desain Formulir Rekam Medis

4) Sistem Pengelolaan Rekam Medis (Sistem Penomoran, Penamaan, Penyimpanan/Penjajaran, Retensi/ Pemusnahan)

5) Manajemen Mutu Rekam Medis

6) Statistik Pelayanan Kesehatan

7) Klasifikasi dan Kodefikasi Penyakit + Terminologi medis dasar (Implementasi ICD di SarYankes)

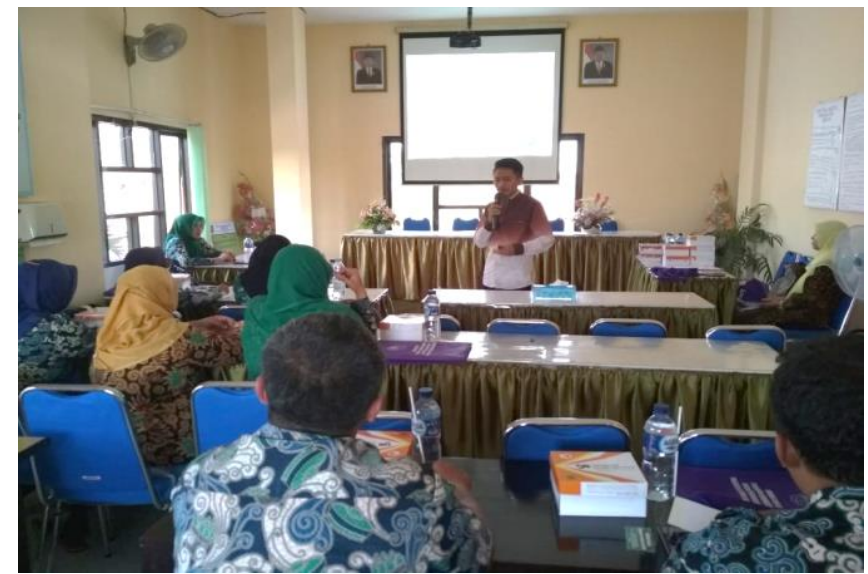

Gambar 3. Penyampaian Materi Manajemen UKRM

c. Evaluasi

Kegiatan pelatihan manajemen rekam medis dan informasi kesehatan, berupa pengantar manajemen RM di puskesmas, pengelolaan UKRM, struktur isi dan desain formulir, klasifikasi kodefikasi penyakit dan mutu dokumen rekam medis. Kegiatan pelatihan ini diikuti $90 \%$ petugas di unit rekam medis puskesmas weru, karena sebagiannya harus tetap bertugas di pelayanan. 


\section{Journal of Community Engagement in Health}

Pelaksanaan kegiatan ini mendapat respon yang baik dari kepala puskesmas dan para peserta yang merupakan petugas di UKRM. Antusiasme ini, diwujudkan dalam bentuk keinginan dari kepala puskesmas weru, bahwa ke depannya dapat diadakan kegiatan pengabdian masyarakat yang berkelanjutan dan sesuai dengan kebutuhan puskesmas weru, terkait pengembangan tata kelola manajemen rekam medis.

Para peserta juga menginginkan ada materi pelatihan tingkat lanjut, sehingga pemahaman dan ilmu mereka, tentang manajemen rekam medis di puskesmas bisa up to date dan dapat digunakan untuk memperbaiki manajemen dan tata kelola di UKRM.

\section{PEMBAHASAN}

Dari hasil diskusi saat pelatihan dan pendampingan, diperoleh beberapa poin yang menjadi masalah utama di unit kerja rekam medis, diantaranya : Kurangnya pengetahuan petugas UKRM di puskesmas tentang manajemen pengelolaan rekam medis yang benar, banyaknya duplikasi No.RM, kurangnya monitoring kualitas dan kelengkapan, ketidaksesuaian kompetensi para petugas UKRM di puskesmas, disebabkan karena kurangnya jumlah lulusan dari tenaga perekam medis. Sehingga mengakibatkan manajemen rekam medis menjadi kurang optimal.

Pelaksanaan kegiatan ini mendapat respon yang baik dari kepala puskesmas dan para peserta yang merupakan petugas di UKRM. Antusiasme ini, diwujudkan dalam bentuk keinginan dari kepala puskesmas weru, bahwa ke depannya dapat diadakan kegiatan pengabdian masyarakat yang berkelanjutan dan sesuai dengan kebutuhan puskesmas weru, terkait pengembangan tata kelola manajemen rekam medis.

Kegiatan pelatihan manajemen rekam medis dan informasi kesehatan, berupa pengantar manajemen RM di puskesmas, pengelolaan UKRM, struktur isi dan desain formulir, klasifikasi kodefikasi penyakit dan mutu dokumen rekam medis. Kegiatan pelatihan ini diikuti $90 \%$ petugas di unit rekam medis puskesmas weru, karena sebagiannya harus tetap bertugas di pelayanan.

Para peserta juga menginginkan ada materi pelatihan tingkat lanjut, sehingga pemahaman dan ilmu mereka, tentang manajemen rekam medis di puskesmas bisa up to date dan dapat digunakan untuk memperbaiki manajemen dan tata kelola di UKRM.

\section{KESIMPULAN}

Simpulan yang diperoleh dari kegiatan pengabdian masyarakat di puskesmas weru antara lain : Petugas puskesmas sudah semakin memahami pengelolaan dan manajemen UKRM di puskesmas, masih banyak ditemukan permasalahan duplikasi No.RM, kurangnya monitoring kualitas dan kelengkapan serta pelaksanaan kegiatan ini mendapat respon yang baik dari kepala puskesmas dan para peserta yang merupakan petugas di UKRM.

Selain itu juga perlu dilakukan pendampingan dan upgrade materi manajemen UKRM di puskesmas yang terbaru, perlu dilakukan identifikasi lebih mendalam dan monitoring penanganan masalah, perlu adanya pelatihan manajemen rekam medis puskesmas tingkat lanjut sehingga sesuai dengan kebutuhan dan perkembangan tata kelola rekam medis di puskesmas. 


\section{DAFTAR PUSTAKA}

Hakam, Fahmi. 2016. Analisis, Perancangan dan Evaluasi Sistem Informasi Kesehatan. Yogyakarta: Gosyen Publishing.

Hakam, Fahmi. 2018. Analisis Penyediaan Rekam Medis Pasien Rawat Jalan Berdasarkan Standar Operasional Prosedur (SOP) Di Puskesmas X. Volume 1 No 1. Jurnal Manajemen Informasi dan Administrasi Kesehatan.

Hakam, Fahmi. 2019. Implementation Of Medical Record Management In Pku Muhammadiyah Hospital Yogyakarta. Volume 2 No 01. Jurnal Manajemen Informasi dan Administrasi Kesehatan.

Hakam, Fahmi. 2014. Pengembangan Sistim Pencatatan Dan Pelaporan Data Di Klinik Muhammadiyah Medical Center. Volume 8 No 2. Jurnal Kesehatan Masyarakat Andalas (JKMA).

Hatta, Gemala R. 2014. Pedoman Manajemen Informasi Kesehatan disarana pelayanan kesehatan. Jakarta: UIP

Hozizah, 2014. Kumpulan Peraturan Perundangan Rekam Medis dan Informasi Kesehatan (Manajemen Informasi Kesehatan). Yogyakarta: Aptirmik Press.

Kementrian Kesehatan RI, 2008. Permenkes No 269 Tahun 2008 Tentang Rekam Medis, Republik Indonesia.

Nurcahyo, A., 2013. Pengembangan Sistem Informasi Rekapitulasi Laporan Rekam Medis Rumah Sakit Kepada Dinas Kesehatan Kabupaten/ Kota Berdasar Ketentuan Kementrian Kesehatan. Jurnal Fakultas Rekayasa Industri Institute Teknologi Telkom Bandung, 2.

Susanto, G. \& Sukadi, 2011. Sistem Informasi Rekam Medis Pada Rumah Sakit Umum Daerah ( RSUD ) Pacitan Berbasis Web Base. Jurnal Sentra Penelitian Engineering dan Edukasi, 3(4), pp.18-24.

Sutisna, E., 2011. Manajemen Kesehatan, Teori dan Praktek di Puskesmas, Yogyakarta: Gadjah Mada University Press.

Rustiyanto, 2011. Manajemen Filing Dokumen Rekam Medis Dan Informasi Kesehatan. Yogyakarta: Politeknik Kesehatan Permata Indonesia.

WHO. 2010. International Statictical Classification of Disease and Related Health Problem Tenth Revision. 